\title{
An Experimental Work on Alkaline Resistance Glass Fiber Reinforced concrete
}

\author{
B.S. Krishnamurthy ${ }^{1}$, R.Balamuralikrishnan ${ }^{2}$, Mohammed Shakil ${ }^{3}$ \\ ${ }^{1}$ Sr. Lecturer, Department of BNE, Caledonian College of Engineering, Muscat, Sultanate of Oman \\ ${ }^{2}$ Asst. Professor, Department of BNE, Caledonian College of Engineering, Muscat, Sultanate of Oman \\ ${ }^{3}$ Student, Department of BNE, Caledonian College of Engineering, Muscat, Sultanate of Oman
}

\begin{abstract}
Conventional concrete has the draw backs of cracks due to plastic shrinkage, low tensile strength compressive strength ratio, low ductility, expansion and contraction with change in temperature. Continuous research efforts are going on to develop a high performance concrete by using fibers and other admixtures. One such effort is the research on an alkaline resistance glass fiber reinforced concrete. GFRC has many advantages over conventional concrete such as It reduce the bleeding of concrete, which improves the surface integrity, homogeneity of concrete and reduces the probability of cracks. Glass fiber reinforced concrete $(G F R C)$ is a composite concrete which has abilities to overcome all these deficiency and make construction faster, resistance of corrosion, durable and can increase the tensile strength of concrete. The alkaline resistance glass fiber reinforced concrete (ARGFRC) resists rust and corrosion and hence contributes to the durability of concrete. In this project, an attempt has been made to study the characteristics strength properties of alkaline resistance glass fiber reinforced concrete for structural applications. Alkaline resistance glass fiber with an aspect ratio of 857.1 were added to C35 grade reference concrete mix as reinforcement in proportions of $0.2 \%$, $0.4 \%, 0.6 \%$ and $1 \%$ by the volume of concrete. $150 \mathrm{~mm} x$ $150 \mathrm{~mm} \times 150 \mathrm{~mm}$ cube moulds, $100 \mathrm{~mm} \times 100 \mathrm{~mm} \times$ $500 \mathrm{~mm}$ beam moulds and $150 \mathrm{~mm}$ diameter and $300 \mathrm{~mm}$ high cylindrical specimens were cast and tested for all the ARGFRC concrete mixes for the C35 grade reference mix for strength comparison. Test is also conducted to study the effect of high temperature. The study shows that $0.6 \%$ addition of A.R glass fibers in ARGFRC has maximum compressive strength, split-tensile strength and flexural strength by $14.98 \%$ with respect to C35 grade reference concrete mix. Similarly, $1 \%$ addition of A.R glass fibers in ARGFRC has minimum characteristics strength by $2.26 \%$ with respect to $C 35$ grade reference concrete mix. 0\% addition of A.R glass fibers in ARGFRC has lowest decrease in high temperature strength by $14.26 \%$ with respect to compressive strength at 28 days. $0.6 \%$ addition of A.R glass fibers in ARGFRC has lowest workability by $74.44 \%$ with respect to $C 35$ grade reference concrete mix
\end{abstract}

and $1 \%$ addition of A.R glass fiber shows a negative trend in workability.

Keywords-Alkaline Resistant Glass fiber reinforced concrete (ARGFRC), Alkaline resistant (A.R) glass fibers, Compressive strength, Split-tensile strength, Flexural strength.

\section{INTRODUCTION}

\subsection{Introduction}

Reinforced concrete has various disadvantages such as shrinkage which cause crack, very low tensile strength to compressive strength ratio, expansive, low ductility, expand and contracts with change in temperature. Efforts are being made to develop a conventional concrete by using fibers and other chemical admixtures. Glass fiber reinforced concrete (GFRC) is a material which has abilities to overcome all these deficiency and make construction faster, resistant to corrosion, durable and can increase the tensile strength.

\subsection{Glass Fiber Reinforced concrete (GFRC)}

A.R glass fiber are reinforced in conventional concrete with other chemical admixtures to develop a discrete discontinuous fibers new composite material name as glass fiber reinforced concrete (GFRC) and which improves the performance of concrete. Due to the presence of discrete fibers, the cracking strength of concrete increases and fiber act as crack arresters.

According to Kariappa and shete, 2016, GFRC is not a new material; it has been used over past 50 years especially in architectural cladding panels, domes, planters and statues. The first GFRC pedestrian bridge was constructed in Israel since 1975 and then after it is used in North America, Asia and Europe. According to Jiff Girard (CCI), 2013, Alkali resistant fibers act as the principle tensile load carrying member while the polymer and concrete matrix binds the fibers together and helps transfer loads from one fiber to another. Without fibers GFRC would not possess its strength and would be more prone to breakage and cracking.

GFRC is used in construction industries because it has many advantages over conventional concrete. It reduces the bleeding of concrete, improves the surface integrity, 
homogeneity of concrete and reduces the probability of cracks. According to Sai Kiran and Rao, 2016, GFRC is a lightweight material which reduces the overall cost as compared to conventional concrete. Research shows that GFRC has achieved high workability, compressive strength, split- tensile strength and flexural strength.

\subsection{Types of Fibers}

According to Kariappa and shete, 2016, fibers have been utilized as reinforcement since ancient times like horsehair used in cement mortar and straw was used in mud bricks. The concept of using composite material was come into early 1950 and glass, steel and synthetic fibers were used in concrete from 1960. The main advantage of fiber is to remove cracks that develop in concrete and to increase the ductility of concrete.

There are many types of fibers such as glass fiber, steel fiber, carbon fiber, cellulose fiber, and polypropylene. Table 1.1 shows the properties and applications of fibers.

\subsection{Glass fiber}

Glass fibers are the strongest fiber used in the reinforced concrete industry and it has many verities for specific use. Glass fibers have ability to increase flexural strength, ductility and resistant to shrinkage of concrete. Glass fibers are used in sewer lining, architectural cladding panel, swimming pools, ducts, roofs etc.

\subsection{Alkaline resistant glass fiber}

Alkaline resistant (A.R) glass fiber is a material made from extremely fine fibers of glass with optimum level of Zirconia $\left(\mathrm{ZrO}_{2}\right)$. It has many applications like it can be used in architectural panel sand Sewer lining, because it resists in contraction with acid, salt, lime and chemicals came from wastewater.

\subsection{Aim}

An experimental study on characteristics strength properties of Alkaline Resistant (AR) Glass Fiber reinforced concrete.

\subsection{Objective}

- To study the characteristics strength properties of C35 grade reference concrete mix.

- To study the characteristics strength properties of C35 grade concrete containing AR Glass fiber with an aspect ratio of 857.1 in proportion of $0.2 \%, 0.4 \%$, $0.6 \%$ and $1 \%$ by the volume of concrete.

- To determine the workability characteristics concrete mixes cast in the project.

- To compare the strength properties of A.R glass fiber reinforced concrete with conventional concrete.

\section{LITERATURE REVIEW}

Different research studies shows that addition of A.R glass fibers in proportions $0.2 \% .0 .4 \%, 0.6 \%$ and $1 \%$ in reference concrete has increased the characteristics strength properties of concrete. Herein below are presented a complication of some research studies carried out on alkaline resistant glass fiber reinforced concrete (ARGFRC)

2.1General

Kariappa \& Shete., 2016. In this paper, the authors have carried out an experimental study on compressive strength, split-tensile strength and flexural strength of alkaline resístanse glass fiber reinforced concrete (ARGFRC). Alkaline resístanse glass fiber with an aspect ratio of 857.1 were added to $\mathrm{M} 30$ grade reference concrete mix as reinforcement in proportions of $0 \%$ to $0.4 \%$ by the weight of cement. $100 \times 100 \times 100 \mathrm{~mm}$ cubes and $100 \times 100 \times 500$ beams specimens are allowed curing for 28 days. 4 mix designs were carried out in the paper with addition A.R glass fibers in varying percentage from $0 \%$ to $0.4 \%$ by the weight of cement. based on this research, the authors have made the following conclusions:

- The slump value and compaction factor increases when $0.4 \%$ A.R glass fibers were added.

- The early 7 days strength properties have decreased and these strength properties have increased at 28 days for the addition of $0.4 \%$ A.R glass fibers.

Kannan, et al., 2010. In this paper, the authors have carried out the experimental study on permeability and compressive strength of super plasticized concrete by adding AR glass Fiber in proportions up to $1 \%$ and superplasticier by the weight of cement. An attempt has been made in this paper to develop a new concrete with good workability and better resistant against permeability with the help of A.R glass fiber and superplasticier.M20 grade GFRC mix design is used in this paper and A.R Glass Fibers were added at $0.2 \%, 0.4 \%, 0.6 \%, 0.8 \%$ and $1.0 \%$ by weight of cement to the reference mix and allowed the test specimens for 28 days curing to test the workability, compressive strength and permeability. The permeability was determined by Steady flow method. Based on the research, the authors have drawn the following conclusions:

- The addition of $0.2 \%$ fiber gives more compressive strength and makes concrete impermeable with good workability.

- The maximum compressive strength got at the addition of $1 \%$ fiber and $0.8 \%$ superplasticier when compare to the reference mix.

Chandramouli, et al., (2010). In this paper, the author has carried out an experimental investigation on the strength properties of concrete with and without A.R glass fibers in proportions for M20, M30, M40 and M50 grade concrete. To make concrete strong in every zone, fibers and chemical admixtures has been reinforced in concrete and a new GFRC is produced. The specimen of $150 \times 150 \times 150 \mathrm{~mm}$ cubes, $100 \times 100 \times 500$ beams and 
$150 \mathrm{~mm} \times 300 \mathrm{~mm}$ cylinders were cast and allowed them for $28,56,90$ and 180 days curing to test bleeding of concrete, workability, compressive strength, split-tensile strength and flexural strength. 4 mix designs were carried out in the paper by adding $0.03 \%$ A.R glass fibers by the weight of concrete volume. Based on the research, the authors have drawn following conclusion:

- The compaction factor achieve 0.93 to 0.97 for almost all grades of concrete and a reduction in bleeding was observed which improve the surface integrity, homogeneity and reduces the probability of cracks when $0.03 \%$ A.R glass fibers were added to the concrete.

- At 28 days, the compressive strength increases 20 to $25 \%$ compare to reference mix for various grades of concrete after addition of A.R glass fiber.

- At 28 days, the flexural and split tensile strength increases 15 to $20 \%$ compare to reference mix for various grades of concrete after addition of A.R glass fiber.

Ghugal, Y.M., Deshmukh, S.B., 2006. .In this paper, the authors have carried out an experimental investigation on the effect of A.R glass fibers on workability, density, compressive, flexural and split tensile strength of M20 grade concrete.M-20 grade of concrete is used in this paper having mix proportions of 1:1.59: 3.70 i.e., cement: fine aggregate: coarse aggregate with w/c ratio of 0.51 . Fibers were added in wet state of concrete and again mixed thoroughly. A.R glass fibers were added in varying percentage 0 to $4.5 \%$ at an interval of $0.5 \%$ by the weight of cement and specimens were cast for curing for 28 days. The test for strength properties were carried out for the fresh and hardened concrete. Based on the research, the authors have made the following conclusions:

- The A.R glass fiber were reduces the workability in terms of slump method and reached $44.44 \%$ when 4.5\% fibers were added in concrete and the wet density of concrete increases with addition of glass fibers. When compare to reference mix at 28 days.

- The average compressive strength, flexural strength and split tensile strength observed $28.46 \mathrm{~N} / \mathrm{mm}^{2}$, $50.08 \mathrm{~N} / \mathrm{mm}^{2}$ and $48.68 \mathrm{~N} / \mathrm{mm}^{2}$ when A.R glass fibers were added in various proportions respectively.

- The flexural member increases the load carrying capacity with addition of glass fiber in concrete as compare to reference mix and this shows that ductility and flexural stiffness has increased due to glass fibers.

Kiran, T. S., Rao, D. K., 2016. In this paper, the authors have carried out an experimental investigationon the behavior of Glass Fiber Reinforcement concrete (GFRC) on compressive, split-tensile and flexural strengths of
M30 grade concrete with and without Alkaline Resistant Glass Fiber (ARGF).M-30 grade concrete is used having mix proportions 1:1.70: 3.06 i.e., cement: fine aggregate: coarse aggregate with w/c ratio of 0.45 . Fibers were added in wet state of concrete and again mixed thoroughly. The fibers were added in varying percentage $0 \%, 5 \%, 6 \%$, and $7 \%$ by the weight of cement and specimens were cast for curing 1,3, 7, 28 and 56 days. Based on the research, the authors have made the following conclusions:

- The maximum compressive strength obtains at the addition of $7 \%$ glass fiber.

- the maximum split tensile and flexural strength obtain at the addition of $6 \%$ glass fiber.

Hemalatha, S., Rose, A.L., 2015. In this paper, the authors have carried out the experimental investigation on GFRC to test the characteristics strength properties and durability of M40 grade concrete. M40 grade of concrete is used having mix proportions 1: 1.5: 2.9 i.e., cement: fine aggregate: coarse aggregate with w/c ratio of 0.40 . The fibers were added in varying percentage of $0.33 \%$, $0.66 \%, 1 \%, 1.33 \%, 1.66 \%$ and $2 \%$ by the weight of concrete volumen and specimens of dimensiones 150x $150 \times 150$ mmcube moulds $100 \times 100 \times 500 \mathrm{~mm}$ beam moulds and $100 \mathrm{~mm}$ dia and $200 \mathrm{~mm}$ height of cylindrical moulds were cast and allowed curing for 7 days, 28 days and 60 days. Based on the research, the authors have made the following conclusions:

- Based on experimental investigation addition of glass fiberin plain concrete increases the strength and durability characteristics.

- Initially addition of glass fiber in the plain concrete the strength characteristics like compressive, flexural and split tensile strength is gradually increased. Finally certain percent addition of glass fiber attain that gradually decrease in strength.

- Maximum compressive, flexural and split tensile strength is attaining in $1.0 \%$ addition of glass fiber. So adding glass fiber up to $1.0 \%$ only not exceeds the limit.

- The durability characteristics gradually increased based on the addition of glass fiber.

\subsection{Summary of literature review}

As observed from the above all literature review, Continuous research efforts are going on to develop a high performance concrete by using fibers and other admixtures. One such effort is the research on an alkaline resistant glass fiber reinforced concrete. GFRC has many advantages over conventional concrete such as It reduce the bleeding of concrete, which improves the surface integrity, homogeneity of concrete and reduces the probability of cracks. Glass fiber reinforced concrete 
(GFRC) is a composite concrete which has abilities to overcome all these deficiency and make construction faster, resistant of corrosion, durable and can increase the tensile strength of concrete. The alkaline resistant glass fiber reinforced concrete (ARGFRC) resists rust and corrosion and hence contributes to the durability of concrete. In general, by the addition of A.R glass fibers in the concrete, a significant improvement in mechanical properties, workability and durability of concrete has been observed. However, the maximum strength of concrete is depend on the amount of A.R glass fiber reinforcing in the concrete because some of the authors failed to increase the workability and durability of concrete due to use of high amount of A.R glass fibers.

\section{EXPERIMENTAL INVESTIGATION}

\subsection{Materials}

\subsubsection{Cement}

Type 1 Cement confirming the code of BS EN 1992-11:2004 from Pioneer Cement Company with specific gravity 3.15 and specific surface air permeability of 328 $\mathrm{m}^{2} / \mathrm{kg}$ will be used throughout the experiment.

\subsubsection{Fine aggregates (F.A)}

Locally available Natural washed sand of size $5 \mathrm{~mm}$ from Oman rocks crusher Al Abyadh with specific gravity of 2.70 and $1.5 \%$ water absorption will be used throughout the experiment.

\subsubsection{Coarse aggregates (C.A)}

A sandstone aggregate of size $20 \mathrm{~mm}$ from Oman rocks crusher Al abyadh with specific gravity of 2.70 and $0.3 \%$ water absorption will be used throughout the experiment.

\subsubsection{Water}

Clean Potable water will be used throughout the experiment. The mix is designed for C35 grade concrete and the mix proportions are shown in Table1.

Table 1 Mix proportion for C35 grade concrete

\begin{tabular}{|c|c|c|c|c|}
\hline Material & Cement & F.A & C.A & Water \\
\hline Quantity & $\begin{array}{c}441 \\
\mathrm{~kg} / \mathrm{m}^{3}\end{array}$ & $\begin{array}{c}769 \\
\mathrm{~kg} / \mathrm{m}^{3}\end{array}$ & $\begin{array}{c}960 \\
\mathrm{~kg} / \mathrm{m}^{3}\end{array}$ & 185 Lit \\
\hline Ratio & 1 & 1.74 & 2.12 & 0.42 \\
\hline
\end{tabular}

3.1.5 Alkaline Resistant(AR) Glass Fibers

A.R glass fibers of Cem - FIL Anti - Crack HD were used in proportions of $0.2 \%, 0.4 \%, 0.6 \%$ and $1 \%$ by the volume of concrete throughout the experiment. The calculation of A.R glass fibers by weight of concrete are presented in Table 2.

Table.2: Volume of fraction of fibers in each mix design

\begin{tabular}{|c|c|c|c|}
\hline $\begin{array}{c}\text { Trial } \\
\text { mixes }\end{array}$ & $\begin{array}{c}\text { Percentage } \\
\text { of A.R } \\
\text { glass fiber }\end{array}$ & Calculation & $\begin{array}{c}\text { Weight of } \\
\text { A.R glass } \\
\text { fiber(g) }\end{array}$ \\
\hline $\mathrm{M} 0$ & $0 \%$ & 0 & 0 \\
\hline
\end{tabular}

\begin{tabular}{|c|c|c|c|}
\hline M1 & $0.2 \%$ & $\begin{array}{c}0.051 \mathrm{~m}^{3} \mathrm{x} \\
0.002 \times 2680 \\
\mathrm{~kg} / \mathrm{m}^{3}\end{array}$ & \\
\hline M2 & $0.4 \%$ & $0.051 \mathrm{~m}^{3} \mathrm{x}$ & 548 \\
& & $\begin{array}{c}0.004 \times 2680 \\
\mathrm{~kg} / \mathrm{m}^{3}\end{array}$ & \\
\hline M3 & $0.6 \%$ & $0.051 \mathrm{~m}^{3} \mathrm{x}$ & 822 \\
& & $0.006 \times 2680$ & \\
& & $\mathrm{~kg} / \mathrm{m}^{3}$ & \\
\hline M4 & $1 \%$ & 0.051 & 1370 \\
& & $\mathrm{~m}^{3} \mathrm{x} 0.01 \mathrm{x}$ & \\
& & $2680 \mathrm{~kg} / \mathrm{m}^{3}$ & \\
\hline
\end{tabular}

3.2 Experiment Setup and plan

Five mix designs have been cast in this experiment by adding in varying percentage of A.R glass fiber in the reference concrete to test the strength properties of concrete. All the specimen were removed from moulds after 24 hours and will place in water for curing at 28 days following are the details of the mixes were cast:

- Mix 0 (M0) or control mix with $0 \%$ of A.R glass fiber

- $\quad$ Mix 1 (M1) with $0.2 \%$ of A.R glass fiber

- $\quad$ Mix 2 (M2) with $0.4 \%$ of A.R glass fiber

- $\quad$ Mix 3 (M3) with $0.6 \%$ of A.R glass fiber

- $\quad$ Mix 4 (M4) with $1 \%$ of A.R glass fiber

The weight of each ingredient for all trial mixes are shown in Table 3.

\subsection{Mixing and Casting procedure}

After finding the appropriate amount of concrete ingredients, the next step is to mixing all the concrete components in specific amount as calculated in table 3.4 for C35 grade and then cast the concrete in the specimens. Following are the procedure for mixing and casting of C35 grade concrete:

Table.3: Each ingredient weight for all trial mixes

\begin{tabular}{|c|c|c|c|c|c|c|}
\hline $\begin{array}{c}\text { Tri } \\
\text { al } \\
\text { mix }\end{array}$ & $\begin{array}{c}\text { Percen } \\
\text { tage of } \\
\text { A.R } \\
\text { glass } \\
\text { fiber }\end{array}$ & $\begin{array}{c}\text { Cemen } \\
\mathbf{t} \\
(\mathbf{k g})\end{array}$ & $\begin{array}{c}\text { F.A } \\
(\mathbf{k g})\end{array}$ & $\begin{array}{c}\text { C.A } \\
(\mathbf{k g})\end{array}$ & $\begin{array}{c}\text { Wat } \\
\mathbf{e r} \\
(\mathbf{k g})\end{array}$ & $\begin{array}{c}\text { A.R } \\
\text { glass } \\
\text { fiber } \\
\mathbf{s} \\
(\mathbf{g})\end{array}$ \\
\hline M 0 & $0 \%$ & 22.50 & 39.21 & 48.96 & 9.43 & 0 \\
\hline M 1 & $0.2 \%$ & 22.50 & 39.21 & 48.96 & 9.43 & 274 \\
\hline M 2 & $0.4 \%$ & 22.50 & 39.21 & 48.96 & 9.43 & 548 \\
\hline M 3 & $0.6 \%$ & 22.50 & 39.21 & 48.96 & 9.43 & 822 \\
\hline M 4 & $1 \%$ & 22.50 & 39.21 & 48.96 & 9.43 & 1370 \\
\hline
\end{tabular}

- Weigh all the ingredients separately as calculated above in the table 3.4. For example, cement: 22.50 
kg, F.A: $39.21 \mathrm{~kg}$, C.A:48.96 kg, water: $9.43 \mathrm{~L}$ for $\operatorname{mix}$ M0.

- Clean the rotary drum mixer machine very well. Also, the mixing and casting procedure should be placed from room temperature $25^{\circ} \mathrm{C}$.

- $\quad$ Place the weighed C.A, F.A and the cement in the mixer and let them mix properly approximate 20 seconds for homogeneity.

- Add weighed water in the mixer and mix thoroughly.

- Add the calculated A.R glass fiber for other trial mixes to impart the workability and increase the strength of concrete.

- Remove the mixed concrete in a big tray and cast the test specimens in removable standard mould like cubes, beams and cylinder as per code BS EN 19921-1:2004.

- Demould the test specimens after 24 hours of casting.

- Keep the test specimens for curing for 28 days to gain the strength of concrete and use them for test the mechanical properties of 5 mixes of concrete.

\subsection{Mechanical properties}

Mechanical properties are necessary to study to get desired objective of the experiment. Some mechanical properties to be test are workability, compressive strength, flexural strength, split- tensile strength and high temperature test as per the code EN1992-1-1for the experiment

\subsection{Test specimens}

There are 6 cubes, 3 cylinder, 3 beams have been cast for each mix. The type of specimen used for the test is shown in Table 4.

Table.4: types of specimens used in experimental work

\begin{tabular}{|c|c|c|c|}
\hline $\begin{array}{c}\text { Type of } \\
\text { specimen }\end{array}$ & $\begin{array}{c}\text { Size of } \\
\text { specimen } \\
(\mathbf{m m})\end{array}$ & $\begin{array}{c}\text { Number } \\
\text { of } \\
\text { specimens }\end{array}$ & $\begin{array}{c}\text { Types of } \\
\text { test }\end{array}$ \\
\hline Cube & $\begin{array}{c}150 \times 150 \times \\
150\end{array}$ & 3 & $\begin{array}{c}\text { Compressive } \\
\text { strength }\end{array}$ \\
\hline Cube & $\begin{array}{c}150 \times 150 \times \\
150\end{array}$ & 3 & $\begin{array}{c}\text { High } \\
\text { temperature } \\
\text { test }\end{array}$ \\
\hline Cylinder & $\begin{array}{c}150(\mathrm{D}) \times \\
300(\mathrm{~L})\end{array}$ & 3 & $\begin{array}{c}\text { Flexural } \\
\text { strength }\end{array}$ \\
\hline Beam & $\begin{array}{c}100 \times 100 \times \\
500\end{array}$ & 3 & $\begin{array}{c}\text { Split-tensile } \\
\text { strength }\end{array}$ \\
\hline
\end{tabular}

Slump test, Compressive strength test, Split - tensile strength test, Flexural strength test, High temperature test were performed on basis of EN1992-1-1.

\section{RESULTS AND DISSCUSSION}

The result and discussions of the control and modified mix with glass fiber and to compare the slump value, compressive strength, flexural strength, split tensile strength and high temperature strength.

\subsection{Workability}

Workability of C35 grade concrete were measures in terms of Slump. According to code EN1992-1-1, the slump values are within the range of $\mathrm{S} 1$ and $\mathrm{S} 2$.

Where, S1: slumps are most likely to be used for curb and pipe work bedding because it is quite a dry concrete mix. This is often referred to as "semi dry" and S2: slumps are used for simple strip footings and cast in-situ hard standing slabs or when using a wheel barrow to move the concrete. This is referred to as a "moist mix" and probably the most useful and most commonly specified consistence. The result of workability is presented in Table 5 and also represented in Fig.1.

Table.5: Results of slump value

\begin{tabular}{|c|c|c|c|}
\hline Mix & $\begin{array}{c}\text { Fiber } \\
\text { content } \\
(\%)\end{array}$ & $\begin{array}{c}\text { Slump } \\
(\mathbf{m m})\end{array}$ & Shape \\
\hline M0 & 0 & 90 & True \\
\hline M1 & 0.2 & 38 & True \\
\hline M2 & 0.4 & 27 & True \\
\hline M3 & 0.6 & 23 & True \\
\hline M4 & 1 & 0 & Zero \\
\hline
\end{tabular}

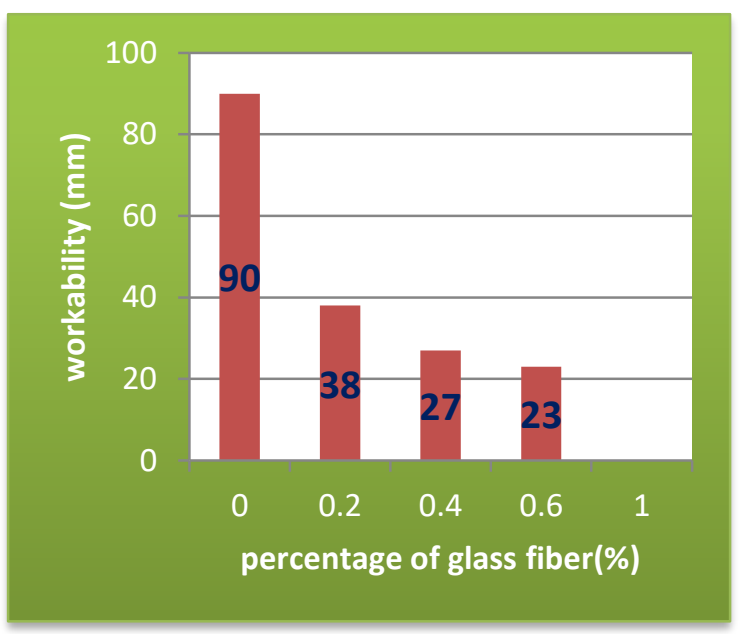

Fig.1: Slump of concrete with different dosage of fiber

From Table 5, it is observed that when compared to control mix, the workability decreased is $57.77 \%$ at $0.2 \%$ fiber content, $70 \%$ at $0.4 \%$ fiber content, $74.45 \%$ at $0.6 \%$ fiber content and $100 \%$ at $1 \%$ fiber content. Hence, the workability of ARGFRC decreases with the increase in fiber content as compared to control mix. The maximum decrease in slump is $100 \%$ observed at $1 \%$ of fiber content. Figure 1 shows the workability results of experimental study in terms of bar chart.

\subsection{Compressive strength}


The compressive strength tests were performed after 28 days of curing of specimens by using universal testing machine (UTM) (Fig.2). The results of the compressive strength for all 5 mix designs are shown in Table 6 and also represented in Fig.3.

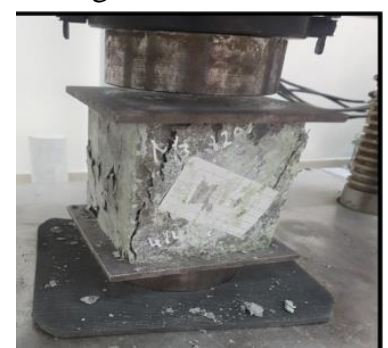

Fig. 2: Compressive strength test

Table.6: Compressive strength test

\begin{tabular}{|l|l|l|}
\hline Mix & $\begin{array}{l}\text { Glass fiber } \\
\%\end{array}$ & $\begin{array}{l}\text { Average } \\
\text { compressive } \\
\text { strength } \mathbf{N} / \mathbf{m m}^{2}\end{array}$ \\
\hline M0 & 0 & 42.05 \\
\hline M1 & 0.2 & 44.25 \\
\hline M2 & 0.4 & 46.25 \\
\hline M3 & 0.6 & 48.35 \\
\hline M4 & 1.0 & 43.00 \\
\hline
\end{tabular}

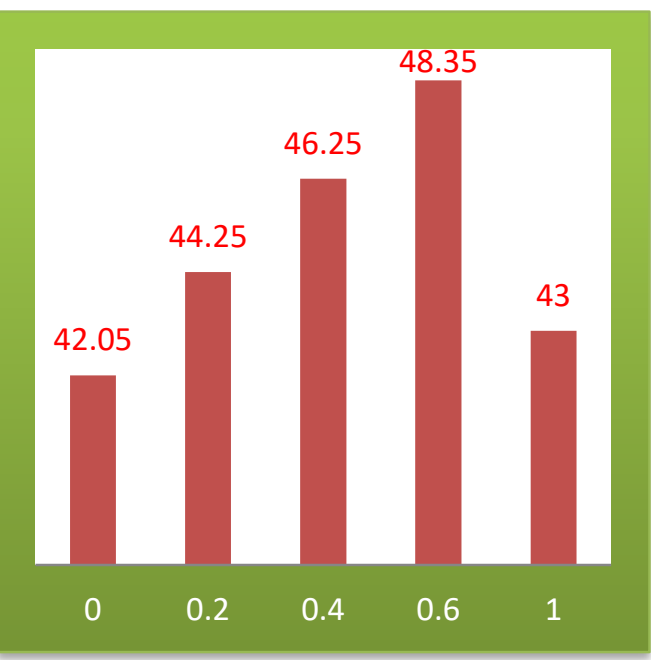

Fig.3(a): Compressive strength with different dosage of fiber

From Table 6, it is observed that when compared to control mix, the strength increased is $5.23 \%$ at $0.2 \%$ fiber content, $9.98 \%$ at $0.4 \%$ fiber content, $14.98 \%$ at $0.6 \%$ fiber content and $2.26 \%$ at $1 \%$ fiber content. Hence, the compressive strength of ARGFRC increases with the increase in fiber content as compared to control mix. However, maximum increase of compressive strength observed at the addition of $0.6 \%$ glass fiber by the volume of the concrete. Figure 3 shows the compressive strength results of the experimental study in terms of bar chart.

\subsection{Split - tensile strength}

The split- tensile strength test was performed after 28 days of curing of specimens by using universal testing machine (UTM) (Fig.3). Table 7 shows the results of the split- tensile strength for all $5 \mathrm{mix}$ designs and Fig. 3 shows the workability results of experimental study in terms of bar chart.

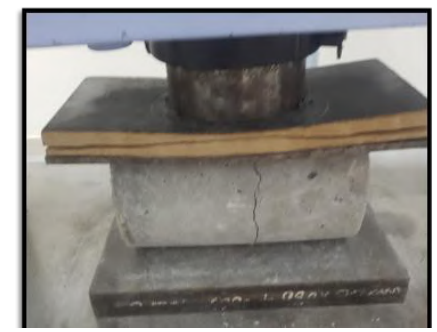

Fig. 3(b): Split tensile strength

Table.7: Split tensile strength test

\begin{tabular}{|l|l|l|}
\hline Mix & $\begin{array}{c}\text { Glass fiber } \\
\text { \% }\end{array}$ & $\begin{array}{c}\text { Average split } \\
\text { tensile strength } \\
\text { N/mm }\end{array}$ \\
\hline M0 & 0 & 4.205 \\
\hline M1 & 0.2 & 4.420 \\
\hline M2 & 0.4 & 4.625 \\
\hline M3 & 0.6 & 4.835 \\
\hline M4 & 1.0 & 4.300 \\
\hline
\end{tabular}

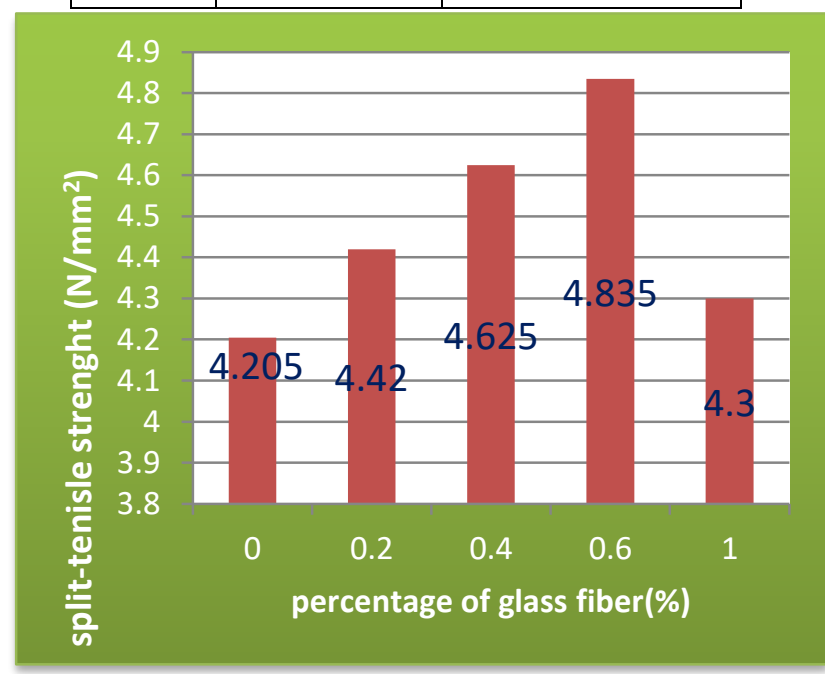

Fig.3(c): Split tensile strength with different dosage of fiber

From Table 7, it is observed that when compared to control mix, the strength increased is $5.23 \%$ at $0.2 \%$ fiber content, $9.98 \%$ at $0.4 \%$ fiber content, $14.98 \%$ at $0.6 \%$ fiber content and $2.26 \%$ at $1 \%$ fiber content. Hence, the Split-tensile strength of ARGFRC increases with the increase in fiber content as compared to control mix. However, maximum increase of Split-tensile strength observed at the addition of $0.6 \%$ glass fiber by the 
volume of the concrete. Figure 3 shows the split- tensile strength results of the experimental study in terms of bar chart.

\subsection{Flexural strength}

The Flexural strength tests were performed after 28 days of curing of specimens by using universal testing machine (UTM) (Fig.4) .Table 8 shows the results of flexural strength for all 5 mix designs and Fig. 4 shows the workability results of experimental study in terms of bar chart.

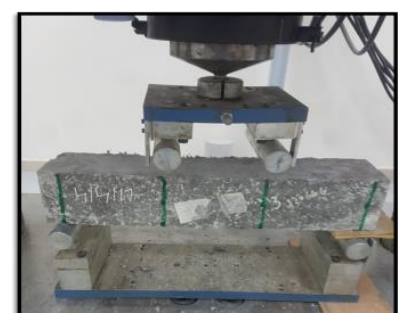

Fig. 4(a): Flexural strength test under two point loading

Table.8: Flexural strength test

\begin{tabular}{|l|l|l|}
\hline Mix & $\begin{array}{l}\text { Glass fiber } \\
\text { \% }\end{array}$ & $\begin{array}{l}\text { Average flexural } \\
\text { strength test } \\
\text { N/mm }\end{array}$ \\
\hline M0 & 0 & 5.256 \\
\hline M1 & 0.2 & 5.530 \\
\hline M2 & 0.4 & 5.781 \\
\hline M3 & 0.6 & 6.043 \\
\hline M4 & 1.0 & 5.375 \\
\hline
\end{tabular}

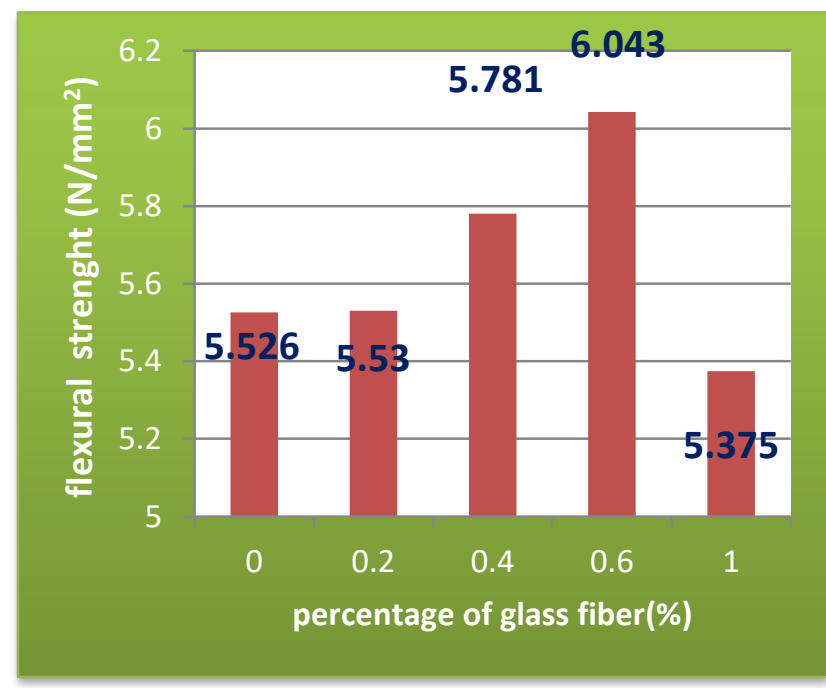

Fig.4(b): Flexural strength test with different dosage of fiber

From Table 8, it was observed that when compared to control mix, the flexural strength is increased $5.21 \%$ at $0.2 \%$ fiber content, $9.98 \%$ at $0.4 \%, 14.98 \%$ at $0.6 \%$, $2.26 \%$ at $1 \%$ fiber content. Hence, the flexural strength of
ARGFRC increases as increase in fiber content. However, the maximum increase is observed at the addition of $0.6 \%$ glass fiber by the volume of concrete. Figure 4 shows the flexural strength results of the experimental study in terms of bar chart.

\subsection{High temperature strength}

The high temperature strength tests were performed after kept the specimens in oven for 24 hours by using universal testing machine (UTM). Table 9 shows the results of high temperature strength for all 5 mix designs and Fig. 5 shows the high temperature strength results of experimental study in terms of bar chart.

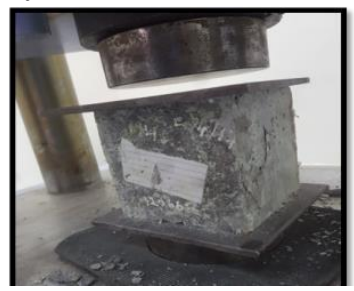

Fig.4(c): High temperature strength test

Table.9: High temperature strength test

\begin{tabular}{|c|c|c|}
\hline Mix & $\begin{array}{c}\text { Glass } \\
\text { fiber } \\
\%\end{array}$ & $\begin{array}{c}\text { Average } \\
\text { temperature } \\
\text { strength } \\
\text { test } \mathbf{N} / \mathbf{m m}^{2}\end{array}$ \\
\hline M0 & 0 & 36.05 \\
\hline M1 & 0.2 & 38.10 \\
\hline M2 & 0.4 & 40.05 \\
\hline M3 & 0.6 & 42.00 \\
\hline M4 & 1.0 & 40.10 \\
\hline
\end{tabular}

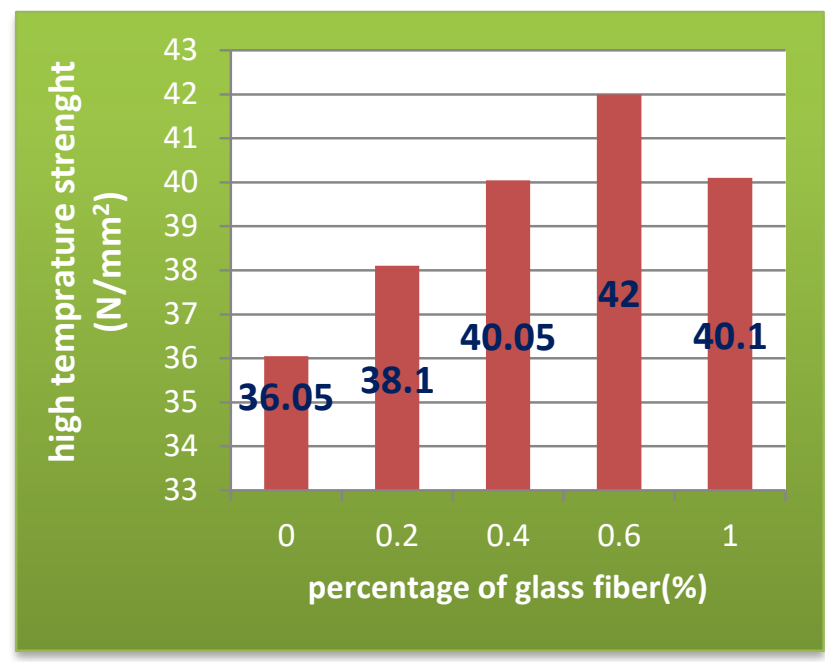

Fig. 5: High temperature strength test with different dosage of fiber

From Table 9, it is observed that when compared to compressive strength of ARGFRC at 28 days for all mixes, the strength is decreased $14.26 \%$ at $0 \%$ fiber 
content, $13.90 \%$ at $0.2 \%$ fiber content, $13.40 \%$ at $0.4 \%$ fiber content, $13.13 \%$ at $0.6 \%$ fiber content and $6.74 \%$ at $1 \%$ fiber content. Hence, the high temperature strength of ARGFRC decreases with the increase in fiber content as compared to compressive strength of at 28 days. Figure 5 shows the high temperature strength results of experimental study in terms of bar chart.

\section{CONCLUSION}

Based on the experimental test and discussion, following conclusions are drawn:

- The compressive strength increased at 28 days of age in comparison of controlled concrete is $5.23 \%, 9.98$ $\%, 14.98 \%$, and $2.26 \%$ by addition of glass fibers in proportions $0.2 \%, 0.4 \%, 0.6 \%$ and $1 \%$ respectively by the volume of the concrete.

- The split- tensile strength increased at 28 days of age in comparison of controlled concrete is $5.23 \%, 9.98$ $\%, 14.98 \%$, and $2.26 \%$ by addition of glass fibers in proportions $0.2 \%, 0.4 \%, 0.6 \%$ and $1 \%$ respectively by the volume of the concrete.

- The flexural strength increased at 28 days of age in comparison of controlled concrete is $5.21 \%, 9.98 \%$, $14.98 \%$, and $2.26 \%$ by addition of glass fibers in proportions $0.2 \%, 0.4 \%, 0.6 \%$ and $1 \%$ respectively by the volume of the concrete.

- $0 \%, 0.2 \%, 0.4 \%, 0.6 \%$ and $1 \%$ addition of Alkaline Resistant glass fibers in ARGFRC, the decrease in high temperature strength is $14.26 \%, 13.90 \%$, $13.4 \%, 13.13 \%$ and $6.74 \%$ respectively over its original compressive strength.

- The workability decreased at 28 days of age in comparison of controlled concrete is $57.77 \%, 70 \%$, $74.45 \%$, and $100 \%$ by addition of glass fibers in proportions $0.2 \%, 0.4 \%, 0.6 \%$ and $1 \%$ respectively by the volume of the concrete.

- Overall, maximum strength was observed for $0.6 \%$ of A.R glass fibers by $14.98 \%$ as compared to reference concrete mix. Similarly, the minimum strength was observed for $1 \%$ of A.R glass fibers by $2.26 \%$ as compared to reference concrete mix.

- Hence, from the results and discussion chapter it can be conclude that the addition of $0.6 \%$ in ARGFRC is satisfactory.

\section{REFERENCES}

[1] Chandramouli, K., Srinivasa, R.P., Pannirselvam, N., Seshadri, S.T., Sravana, P. Strength Properties of Glass Fiber Concrete, ARPN Journal of Engineering and Applied Sciences. 5(4), p 20-30, 2010.

[2] Hemalatha, S., Rose, A.L. Experimental study on properties of glass fiber reinforced concrete,
International Research Journal of Engineering and Technology (IRJET). 3(4), p. 2285-2289, 2016.

[3] Ghugal, Y.M., Deshmukh, S.B. Performance of Alkali-resistant Glass Fiber reinforced concrete, Journal of Reinforced Plastics and Composites. 25(6), p 40-48, 2006.

[4] Kannan, S.U., Selvamony, C., Ravikumar, M.S., Gnanappa, S.B. Investigations and Study on The Effect of AR Glass Polymer Fibres in Selfcompacting Self-curing Concrete: ARPN Journal of Engineering and Applied Sciences. 5(2), p.38-43, 2010.

[5] Kariappa, M. S., Shete, G.N. Experimental Study on the Performance of Alkali Resistant Glass Fibre, International Journal of Emerging Trends in Science and Technology. 3(5), p. 3915-3922, 2016.

[6] Kiran, T. S., Rao, D. K. Mechanical properties of glass fiber reinforced concrete: International Journal of Civil and Structural Engineering Research, p.167-173, 2016.

[7] The concrete countertop Institute, blog by Jeff Girard, Raleigh, NC, 2013. 